Research Paper

\title{
Synthesis of Alkyd Resin Modified with Waste Palm Cooking Oil as Precursor Using Pretreatment with Zeolite Adsorbent
}

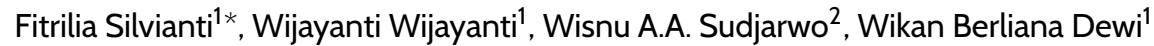 \\ ${ }^{1}$ Politeknik ATK Yogyakarta, Jl. Ateka, Bangunharjo, Sewon, Bantul, Yogyakarta, Indonesia \\ ${ }^{2}$ Fakultas Teknik, Universitas Setia Budi, Jl. Letjend Sutoyo Mojosongo, Surakarta, Indonesia \\ ${ }^{*}$ Corresponding author: fitrilia.s@atk.ac.id
}

\begin{abstract}
Research on synthesis of alkyd resin (AR) modified with waste palm cooking oil (WPCO) as precursor using alcoholys-polyesterification method was successfully conducted. The modified alkyd resin was characterized using Fourier Transform Infrared Spectroscopy (FTIR) and Thermogravimetry-Differential Thermal Analysis (TG-DTA). The pretreatment was carried out for WPCO by applying adsorption technique using zeolites to remove free fatty acid (FFA). Modified alkyd resin was synthesized with the main ingredients composition consisting of WPCO, glycerol, anhydrous phthalate with the oil length of $40 \%$ at the total weight of 27.54 grams, and a small amount of $\mathrm{CaO}$ as catalyst. The characterization result using FTIR showed the presence of typical alkyd resin compound group at the absorption peaks 1597.06 and 1651.07 consecutively as the vibration of benzene ring from the phthalate and $C=C$ stretching of unsaturated fatty acids. The thermal characterization was performed by using TG-DTA analysis showing that the transition glass and recrystallization at the temperature $390.25^{\circ} \mathrm{C}$ and $482.46^{\circ} \mathrm{C}$ respectively.
\end{abstract}

Keywords

Modified alkyd resin, waste palm oil, zeolites, adsorption

Received: 12 March 2018, Accepted: 24 July 2018

https://doi.org/10.26554/sti.2018.3.3.119-122

\section{INTRODUCTION}

Alkyd resin is an additive that serves as a binder in the paint industry, coating, plastic industry, adhesives, etc. Alkyd resin is widely used in anti-corrosion coating industry, such as in automotives and shipbuilding industry. Alkyd-based coating are well-known for good corrosion protection, high gloss, and the ease of application even over poorly teated surface (Gan and Tan, 2001). They are used for protecting surfaces against various environmental effects like UV-radiation, chemical invasion and mechanical stresses (Oladipo et al., 2013). Alkyd resin specifically can be called as a plasticizer in the manufacture of plastics. The use of alkyd resin is important in manufacturing industry to provide additional strength, flexibility, endurance, and other positive properties (Momodu et al., 2011; Atta et al., 2013; Haryono et al., 2005). Alkyd resins are unsaturated hydroxylated polyesters resins modified with vegetables/marine oils or their fatty acid. Therefore alkyd resins are main product of poly condensation reactions between poly carboxylic acids and poly alcohol in presence of fatty acids or vegetable oils (Ibrahim et al., 2014). Oil modified alkyd resins are usually prepared via alcoholysis and polyesterification of polyhydric alcohols and dibasic acids together with the modifiying oils.
The basic reaction of alkyd resin is esterification, which shown below:

$$
\mathrm{R}-\mathrm{COOH}+\mathrm{ROH} \longrightarrow \mathrm{RCOOR}+\mathrm{H}_{2} \mathrm{O}
$$

Alkyd resins used in industry are still dominated by derivative products from petroleum, especially the phthalate group. In fact, phthalates can be degraded into digestion, such as Di-2-ethylhexyl phthalate (DEHP) because alkyd resins from petroleum are less heat-resistant (Haryono et al., 2005; Waskitoaji et al., 2012). The petroleum based products are expected to decline in future years because their unrenewable properties. Nowadays, some research are conducted to try finding the subtitute of petroleum with renewable natural resources, such as plants and animals oils. Several research studies have begun to switch to vegetable oil as a modified alkyd resin substituent because it is considered safer, non-toxic, and biodegradable by having properties as alkyd resins similar to petroleum derivatives (Haryono et al., 2005; Waskitoaji et al., 2012; Vaidya et al., 2012; Galli et al., 2014). Therefore , it is also important for companies to develop alternative sources which is decrease their production cost.

Alkyd resins modified with vegetable oils have been produced in industries such as soybean oil, sunflower seed oil, and 
castor oil (Haryono et al., 2005). Alkyd resin contains agro (50$70 \%$ ) and petroleum (25\%) base raw materials as compared to commercials resin contain $50-70 \%$ petroleum based products is highly hydrophilic, hence it can be used in emultion polymer synthesis (Uzoh et al., 2013). The development of modified alkyd resin using vegetable oil began to be expanded because of its good result compared to alkyd resin of petroleum oil, in addition to its better price and productivity.

Some research on the synthesis of alkyd resin using various vegetable oil precursors has shown the good results based on the parameters of alkyd resin properties. Menkiti and Onukwuli (2011) studied the relation between oil length variation and the properties of rubber-seed oil based alkyd resin products. In addition, Igbo et al. (2014) examined the modification of sesame oil-based alkyd resin. Shaker et al. (2012) also did the research on jojoba oil-modified alkyd resins according to the standard parameters of alkyd resin. Meanwhile, Isaac and Nsi (2013) successfully synthesized cotton-based oil-based alkyd resins with polybasic acid variables. Based on those studies on the precursor of alkyd resin, it can be concluded that alkyd resin can be produced using vegetable oil. Vegetable oil industry, especially palm oil is a large industry in line with its use. A number of food industries consume a lot of cooking oil, such as crackers industry and restaurants potentially provide waste cooking oil. The post-processing of frying makes the cooking oil become harmful waste because it could cause damage to the liver, heart, and blood vessels as what was tested on Wistar rats (Rukmini, 2007). On the other hands, if WPCO is disposed to the enviroment may cause large contamination. One of the way to utilize this waste palm cooking oil is to make it as a precursor for alkyd resin synthesis.

In the synthesis process of alkyd resin, vegetable oil is often supplemented with a polyol compound, such as glycerol or pentaerythritol for the occurrence of an alkylolysis process that produces monoglycerides, before the alkyd resin esterification process is carried out (Menkiti and Onukwuli, 2011; Igbo et al., 2014). It is interesting that the heating process of cooking oil will trigger a hydrolysis process that produces glycerol and free fatty acids (Aziz et al., 2013). Therefore, glycerol from the used cooking oil will become polyols in the synthesis of alkyd resin by removing the product-free fatty acids from the hydrolysis of cooking oil first. However, the comparison of the results using additional glycerol in the alkoholys process is still required. The previous research, based on patent EP 1984 $420 \mathrm{~B} 1$, has succesfully synthesized a fat-based polymer using a glycerin-based alcoholic process.

The process of removing free fatty acids from used cooking oil is done by adsorption technique using zeolite. Based on US patent 6229032 B1 (P.A et al., 2001) and the previous research by Taylor et al. (1984), the removal of free fatty acids using zeolites has already been conducted. In general, zeolites are crystalline aluminosilicates in which the three components, namely aluminium, silicon, and oxygen, are arranged in a fixed, dimensional framework with cavities and pores of uniformed size and shape. The Zeolite network is composed of $\mathrm{SiO}_{4}$ and
$\mathrm{AlO}_{4}$ tetrahedra in which the negative charge on the latter is neutralised by cations like metal ions, ammonium ions, or alkali metal ions.

\section{EXPERIMENTAL SECTION}

\subsection{Time and Place of Research}

This research was conducted from October 2016 until November 2016 at the Laboratory of Waste Treatment Politeknik ATK Yogyakarta. Characterization of materials was conducted in the Laboratory of Instrumentation and Polymer Technology Politeknik ATK Yogyakarta and Laboratory of Organic Chemistry Universitas Gadjah Mada.

\subsection{Materials and Instrumentations}

Materials used in this study were waste palm cooking oil taken from crackers home industry at Bantul Yogyakarta and zeolites adsorbent industrial grade. The chemicals were pure products of analytical quality, i.e. glycerol, anhydrous phthalate, $\mathrm{CaO}$, $\mathrm{KOH}$, ethanol 95\%, Xylene, phenolpthalein. The characterizations were done by FTIR (Shimadzu 8201PG) and TG-DTA (Perkin Elmer Diamond) under air atmosphere from 30 to $1000^{\circ} \mathrm{C}$ at a heating rate of $10^{\circ} \mathrm{C} \cdot \mathrm{min}^{-1}$. The equipments were used such as glassware, batch system equipment (three neck boiling flask, glass condenser), magnetic stirrer, thermometer and shaker.

\subsection{Methods}

\subsubsection{Pretreatment of WPCO}

Pretreatment of the waste palm cooking oil was conducted by applying adsorption method using $0.3 \mathrm{~g}$ zeolite in $150 \mathrm{~mL}$ cooking oil which was heated around $100^{\circ} \mathrm{C}$ for 2 hours. The percentage of FFA was determined using AOCS method with few modification. Fifty $\mathrm{mL}$ of ethanol were used to dissolve $2 \mathrm{~g}$ of sample and titrated against $0.1 \mathrm{~N}$ sodium hydroxide solution. FFA was expressed as palmitic acid

\subsubsection{Synthesis of alkyd resin}

The synthesis of alkyd resin was carried out with the main ingredients composition of cooking oil, glycerol, and anhydrous phthalate with an oil length of $40 \%$ and a total weight of 27.54 grams. In the synthesis process, the oil was mixed with glycerol and a small quantity of $\mathrm{CaO}$ as a catalyst. This mixture was heated in a heating mantle at the temperature of $230-250{ }^{\circ} \mathrm{C}$ for 2 hours. To indicate the reaction, after two hours a little amount of aliquot was taken to check the solubility in Methanol as a sign of the formation of monoglyceride. Then, at the onset of the second phase, the temperature of reaction was lowered to $180{ }^{\circ} \mathrm{C}$.

Anhydrous phtalate was added as dissolved in Xylene by $10 \%$ of total weight charged of the mixture. Aliquots were taken every 30 minutes to check the decrease in the number of acid. The reaction was stopped when the number of acid reached $10 \mathrm{mg} \mathrm{KOH} \mathrm{g}{ }^{-1}$. The determination of acid amount used the procedure of AOCS method. Then, alkyd resin as the result was cooled and characterized with FTIR. 


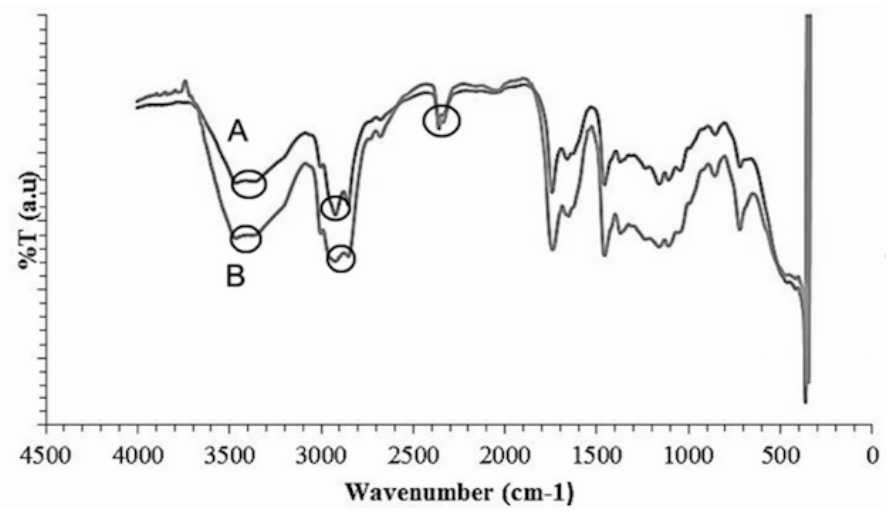

Figure 1. FTIR Spectra of WPCO (A) Before Adsorption; (B) After Adsorption

\section{RESULTS AND DISCUSSION}

The pretreatment of WPCO was done before the synthesis which used adsorption method with zeolite as the adsorbent to remove the free fatty acid. The adsorption was done in 150 $\mathrm{mL}$ WPCO compounded with $0.3 \mathrm{~g}$ zeolite which was heated around $100{ }^{\circ} \mathrm{C}$ for 2 hours. After the adsorption, the \% FFA was checked using AOCS method, and the value was $0.003 \%$.

The characterization of WPCO before and after the adsorption were analyzed using FTIR. The FTIR spectra shown in Figure 1 illustrates the functional group of oil in general. It shows the peak of $-\mathrm{OH}$ at $3464.15 \mathrm{~cm}^{-1}, \mathrm{C}=\mathrm{O}$ at 1743.65 $\mathrm{cm}^{-1}$, and $-\mathrm{CH}$ at $2924.09 \mathrm{~cm}^{-1}$. The FFA property is related to a large part of spectrum, such as the bands due to bonded $\mathrm{O}-\mathrm{H}, \mathrm{C}=\mathrm{O}$ stretching in ester, $\mathrm{C}-\mathrm{H}$ and the fingerprint region of oil at $1500-1000 \mathrm{~cm}^{-1}$ (Man, 1999). The qualitative result which was based on the FTIR data demonstrated that the FFA in WPCO after the adsorption was reduced compared to that in WPCO before the adsorption. The intensity number of $-\mathrm{OH},-\mathrm{C}=\mathrm{O}$, and $-\mathrm{CH}$ bands before adsorption was higher compared to that after adsorption. Besides, some of the bands in the fingerprint of oil region were shifted.

The characterization of alkyd resin and FTIR in comparison to WPCO after the adsorption is presented in Figure 2. The FTIR spectra showed the presence of a typical alkyd resin compound group at the absorption peak of $1597.06 \mathrm{~cm}^{-1}$ due to the vibration of benzene ring from the phthalate. It also occurred in the absorption at $1651.07 \mathrm{~cm}^{-1}$ because of the $\mathrm{C}=\mathrm{C}$ stretching of the unsaturated fatty acids, as well as a characteristic of chain ester band at $1735.93 \mathrm{~cm}^{-1}$. The presence of $\mathrm{O}=\mathrm{C}-\mathrm{O}-\mathrm{C}$ also exhibits the characteristic of ester bands at $1126.43 \mathrm{~cm}^{-1}$ (Uzoh et al., 2013). The absorption of C-O alicyclic also appeared at $1072.42 \mathrm{~cm}^{-1}$. FTIR spectra of WPCO showed the vibration peak of stretching $\mathrm{C}=\mathrm{O}$ from ester triglyceride group at 1743.65 , while in alkyd resins spectra appeared in 1735.93. The absorption peak vibration of stretching $\mathrm{OH}$, aliphatic C-H stretching and C-H bending appeared in both WPCO and alkyd resin spectra at $3464.15 \mathrm{~cm}^{-1}, 2924.09$ $\mathrm{cm}-1$, and $1458.18 \mathrm{~cm}^{-1}$.

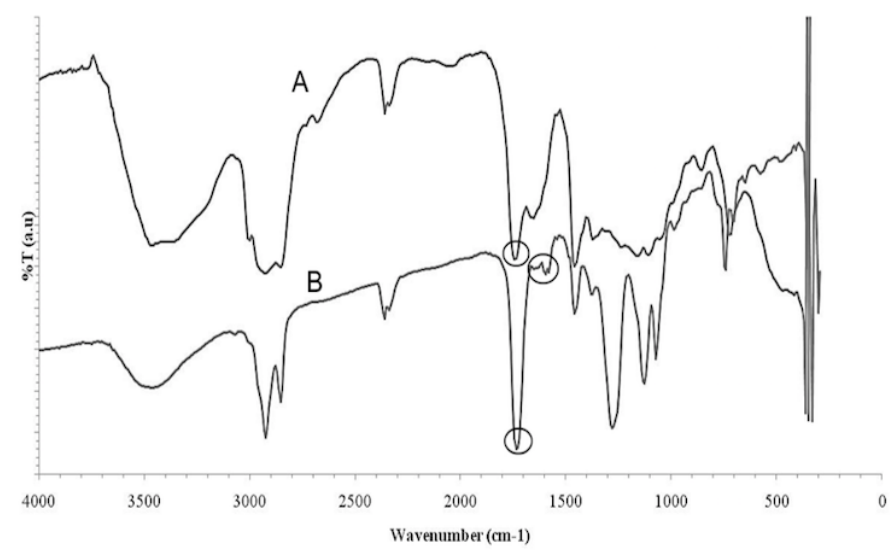

Figure 2. FTIR Spectra of (A) WPCO after adsorption; (B) Alkyd Resin Modified WPCO

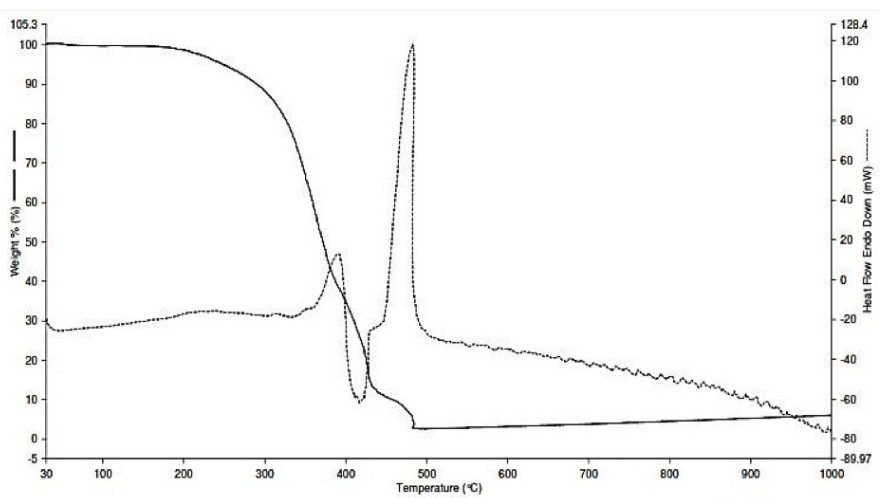

Figure 3. TG-DTA Thermogram of Alkyd Resin Modified WPCO

The thermal properties of AR was studied using TG-DTA. About $9.981 \mathrm{mg}$ of the sample was heated under the air atmosphere from 30 to $1000{ }^{\circ} \mathrm{C}$ at a heating rate of $10{ }^{\circ} \mathrm{C}$. $\mathrm{min}^{-1}$. The TG-DTA thermogram shown in Figure 3 showed melting, recrystallisation and further melting. The transition glass and recrystallization occured at $390.25^{\circ} \mathrm{C}$ and $482.46^{\circ} \mathrm{C}$ respectively. Thermogram TG-DTA of AR showed the degradation at four stages.

The first stage was at temperature 180 to $332.62{ }^{\circ} \mathrm{C}$ with the weight reduction of $22.368 \%$. The second stage is endothermic reaction starting at $332.62{ }^{\circ} \mathrm{C}$ to $387.88^{\circ} \mathrm{C}$ with the weight reduction of $60.669 \%$. The third stage occured at temperature $387.88^{\circ} \mathrm{C}$ to $429.27^{\circ} \mathrm{C}$ and exothermic reaction with the weight reduction of $85.308 \%$. The fourth stage was endothermic reaction which occured at temperature 429.27 to 498.53 ${ }^{\circ} \mathrm{C}$ with the weight loss $97.712 \%$. The TGA curve showed better degradation behavior of alkyd resin compared to alkyd resin based on PET waste and camelina sativa oil. Alkyd resin based on PET waste has $75 \%$ weight loss at $375^{\circ} \mathrm{C}$ (Güçlü, 2009) and $70 \%$ weight loss at $388^{\circ} \mathrm{C}$ (Acar et.al, 2012). Additionally, alkyd resin based on camelina sativa oil has $60 \%$ weight loss at 
$398^{\circ} \mathrm{C}$ (Nosal et al., 2015).

\section{CONCLUSIONS}

The result has revealed that alkyd resin modified with waste palm cooking oil precursor which was pretreated with zeolites adsorption technique could be synthesized by alcoholyspolyesterification method. In general, the result of characterization showed the presence of a typical alkyd resin compound group at the absorption peak 1597.06 and 1651.07 as the vibration of benzene ring from the phthalate and $\mathrm{C}=\mathrm{C}$ stretching of unsaturated fatty acids.

\section{REFERENCES}

Atta, A. M., R. A. El-Ghazawy, and A. M. El-Saeed (2013). Corrosion Protective Coating Based on Alkyd Resins Derived from Recycled Poly(ethylene terephtalate) Waste for Carbon Steel. Int. J. Electrochem, 8; 5136 - 5152

Aziz, I., S. Nurbayti, and J. Suwandari (2013). Pembuatan Gliserol dengan Reaksi Hidrolisis Minyak Goreng Bekas (Synthesis of Glycerol with Hydrolysis Reaction of Used Cooking Oil). Chem. Prog, 6(1); 19-25

Galli, F., S. Nucci, C. Pirola, and C. L. Bianchi (2014). Epoxy methyl soyate as bio-plasticizer: two different preparation strategies. Chemical Engineering Transactions, 37; 601-606

Gan, S.-N. and B.-Y. Tan (2001). FTIR studies of the curing reactions of palm oil alkyd-melamine enamels. Journal of Applied Polymer Science, 80(12); 2309-2315

Güçlü, G. (2009). Alkyd resins based on waste PET for waterreducible coating applications. Polymer Bulletin, 64(8); 739748

Haryono, A., R. H. Nugroho, E. Triwulandari, and W. S. R. (2005). Plasticizer from Vegetable Oil Derivatives : A Review. In Prosiding Simposium Nasional Polimer $V$. page 240-247

Ibrahim, K. A., K. A. Abu-sbeih, I. Al-Trawneh, and L. Bourghli (2014). Preparation and Characterization of Alkyd Resins of Jordan Valley Tomato Oil. Journal of Polymers and the Environment, 22(4); 553-558

Igbo, U. E., , C. C. Igwe, E. Akubueze, O. R. Ishiola, A. O. Odusote, and A. O. Oyewole (2014). Utilisation of Beniseed Oil for the Production of Alkyd Resin. IOSR Journal of Applied Chemistry, 7(5); 104-106

Isaac, I. O. and E. W. Nsi (2013). Influence of Polybasic Acid Type on the Physicochemical and Viscosity Properties of Cottonseed Oil Alkyd Resins. The International Journal of Engineering and Science, 2(5); 1-14
Menkiti, M. C. and O. D. Onukwuli (2011). Utilization Potentials of Rubber Seed Oil for The Production of Alkyd Resin Using Variable Base Oil Lengths. ,. New York Science Journal, 4; 51-59

Momodu, V. M., S. O. Omorogbe, E. U. Ikhuoria, E. O. Obazee, and A. I. Aigbodion (2011). Synthesis and Evaluation of Performance Characteristics of Walnut (Tetracarpidium conophorum) Seed Oil-Modified Alkyd Resin,. Researcher, 3 (7), 3(7); 63-66

Nosal, H., J. Nowicki, M. Warzała, E. Nowakowska-Bogdan, and M. Zarębska (2015). Synthesis and characterization of alkyd resins based on Camelina sativa oil and polyglycerol. Progress in Organic Coatings, 86; 59-70

Oladipo, G. O., I. C. Eromosele, and O. M. Folarin (2013). Formation and Characterization of Paint Based on Alkyd Resin Derivative of Ximenia americana (Wild Olive) Seed Oil. Environment and Natural Resources Research, 3(3)

P.A, J., P. Maes, S. Paulussen, M. Tielen, and D. Steenkiste (2001). Elimination of trans-unsaturated fatty acid compounds by selective adsorption with zeolites

Rukmini, A. (2007). Regenerasi Minyak Goreng Bekas dengan Arang Sekam Menekan Kerusakan Organ (Regeneration of Used Cooking Oil with Coal Chaff to Reduce Organ Damage). In Proceeding Seminar Nasional Teknologi, A1-A9

Shaker, N. O., N. A. Alian, and M. M. El-sawy (2012). Preparation, Characterization and Evaluation of Jojoba Seed Oil-Modified Alkyd Resins. Der Chemica Sinica, 3(5); 1157-1162

Taylor, D. R., C. B. Ungermann, and Z. Demidowicz (1984). The adsorption of fatty acids from vegetable oils with zeolites and bleaching clay/zeolite blends. Journal of the American Oil Chemists' Society, 61(8); 1372-1379

Uzoh, C., O. Onukwuli, R. Odera, and S. Ofochebe (2013). Optimization of polyesterification process for production of palm oil modified alkyd resin using response surface methodology. Journal of Environmental Chemical Engineering, 1(4); 777-785

Vaidya, R., G. Chaudhary, N. Raut, G. Shinde, and N. Deshmukh (2012). Synthesis of Biocomposites from Natural Oil-A Review. In Proceeding of IPCBEE, volume 41. page $55-60$

Waskitoaji, A., E. Triwulandari, and A. Haryono (2012). Synthesis Plasticizers Derived from Palm Oil and Their Application in Polyvynil Chloride. In Procedia Chemistry, volume 4. page 313-321 